\title{
Olhar comum às visões plurais: os Festivais de Cinema Indígena no Brasil ${ }^{1}$
}

\author{
Mirada común a las visiones plurales: los Festivales de Cine Indígena en \\ Brasil
}

\section{Common view to plural visions: the Indigenous Film Festivals in Brazil}

\author{
Luciana de Paula Freitas ${ }^{2}$
}

\begin{abstract}
Resumo
Nos últimos dez anos, o número de Festivais de Cinema voltados exclusivamente à temática Indígena cresceu em território latino-americano. Este trabalho pretende mapear a existência desses Festivais no Brasil e, para tal, reflete de que forma o contexto de globalização e sua íntima relação com o aparato audiovisual gera mecanismos de produções outras, que, neste caso, refere-se à produção protagonizada por indígenas. De modo que também analisaremos aspectos imagéticos através de uma perspectiva ameríndia e multinaturalista. E por fim, a investigação sobre os festivais de cinema, sua presença no Brasil e na América Latina.
\end{abstract}

Palavras-Chave: Cinema Indígena, Festivais de Cinema, Globalização; Multinaturalismo, pele de imagem.

\section{Resumen}

En los últimos diez años, el número de Festivales de Cine dirigidos exclusivamente a la temática Indígena ha crecido en territorio latinoamericano. La presente investigación pretende mapear la ocurrencia de esos Festivales en Brasil y, para ello, muestra de qué forma el contexto de globalización y su íntima relación con el equipo audiovisual genera mecanismos de producciones otras, que, en este caso, se refiere a la producción protagonizada por indígenas. De modo que también analizaremos aspectos imagéticos a través de una perspectiva amerindia y multinaturalista. Y por fin, la investigación sobre los festivales de cine, su presencia en Brasil y en América Latina.

Palabras claves: Cine Indígena, Festivales de Cine, Globalización, Multinaturalismo, piel de imagen.

\section{Abstract}

In the last ten years, the portion of Film Festivals focused exclusively on the Indigenous theme has grown in Latin American territory. This work pretends to map the existence of these Festivals in Brazil and shows how the context of globalization and its intimate relation with the audiovisual devices generates mechanisms of other productions, which, in this case, refers to the production carried out by natives. So we will also analyze imagery from an Amerindian and multinaturalist perspective. And finally, the research on film festivals, their presence in Brazil and Latin America.

Keywords: Indigenous Cinema, Film Festivals, Globalization, Multinaturalism, skin of image.

\footnotetext{
${ }^{1}$ Artigo apresentado no Simpósio Temático “Jovens Pesquisadores Latino-americanos" durante o II Seminário Latino-Americano de Estudos em Cultura - SEMLACult em Foz do Iguaçu/PR, Brasil, 2018.

2 (Mestranda no programa de Pós-Graduação Interdisciplinar em Estudos Latino-Americanos; Universidade Federal da Integração Latino-Americana - UNILA; Foz do Iguaçu, Paraná, Brasil; lucianastk @ hotmail.com)
} 


\section{Introdução}

O número de Festivais de Cinema voltados à circulação de filmes etnográficos tem crescido exponencialmente nos últimas décadas, com intensificação a partir dos anos 1990, quando a França se torna pioneira na produção dos aparelhos portáteis e concebe um novo modo de produção, gerando outra lógica de distribuição e exibição das peças audiovisuais. Mesclado também com os processos globalizadores latentes nesse momento e que, segundo Canclini

[...] acentuam a interculturalidade moderna quando criam mercados mundiais de bens materiais e dinheiro, mensagens e migrantes. Os fluxos e as interações que ocorrem nesses processos diminuíram fronteiras e alfândegas, assim como a autonomia das tradições locais; propiciam mais formas de hibridação produtiva, comunicacional e nos estilos de consumo do que no passado. Às modalidades clássicas de fusão, derivadas de migrações, intercâmbios comerciais e das políticas de integração educacional impulsionadas por Estados nacionais, acrescentam-se misturas geradas pelas indústrias culturais. (CANCLINI, 2008, P. 31)

Esses fatores ocasionaram, alinhados a outra série de elementos, o contato de comunidades indígenas com o aparato audiovisual. Agora não como o tema ou espectadores, mas também como produtores e protagonistas. Os cineastas indígenas são uma nova e potente geração para o cinema não só brasileiro, como também mundial, acarretando na necessidade e urgência de espaços voltados a esses tipos de produção, tal como são os Festivais de Cinema Indígena. Mattos (p. 1) expõe que:

Nas últimas décadas observamos uma forte tendência de crescimento no número de festivais audiovisuais, tanto no Brasil, quanto no exterior. Uma das características observadas neste fenômeno internacional, diz respeito ao surgimento de inúmeros festivais com perfil segmentado, isto é, festivais que se situam na fronteira entre campos culturais distintos como o cinema e as questões de gênero, diversidade sexual, cinema e infância, cinema e "periferia", cinema e ambiente, cinema e acessibilidade, cinema e esporte, cinema e futebol, entre tantos outros. (MATTOS, p. 1)

Festivais de Cinema Indígena demarcam uma etnografia mais geral - em Festivais onde outrora encontrava-se o maior fluxo de cinema indígena - e traz debates do que são as cosmovisões, tradições, vivências, problemáticas enfim, cultura indígena para as telas, dentro de uma área que ancestralmente ocupam: de trabalhar com contar histórias, representar e grafar. A cultura indígena encontra-se exatamente na raiz e origem deste território que hoje se conhece como Brasil. O IBGE, no censo de 2010, traz listado 254 povos indígenas no Brasil, sendo 896.917 pessoas. Destes, 324.834 vivem em cidades e 572.083 em áreas rurais, o que corresponde aproximadamente a $0,47 \%$ da população total do país. Parcela esta que encara diversas barreiras para manter-se vivo frente a uma cultura inicialmente colonialista europeia, que hoje atua travestida de outros modos, formada por anos de extermínio. 
Como dito, o cinema é um dispositivo que tem sido cada vez mais utilizada por essa população, mas ainda falta suporte. A Ancine, maior braço de fomento audiovisual de âmbito federal no Brasil hoje, nunca disponibilizou editais indígenas dentro de seus Programas. Houve um maior estímulo durante os anos 1990 com a criação do projeto Vídeo Nas Aldeias e posteriormente na gestão de Gilberto Gil (2003-2008) no Ministério da Cultura, onde foram criados os Pontos de Cultura que acabou financiando experiências audiovisuais feitas por indígenas.

Os festivais especificamente voltados para a produção audiovisual indígena que vem surgindo ainda não possuem dados concretos nem levantamentos gerais, de forma que este trabalho preza pelas informações aqui buscadas sabendo que servirão de estudos para quem se interessa por tal temática e fenômeno.

Temos como objetivo então mapear quais são os festivais de cinema indígena existentes no Brasil e como atuam. Mais especificamente, traçar um panorama do cinema indígena no Brasil e discorrer sobre imagens a partir de uma visão ameríndia e multinaturalista, contrastando com as do multiculturalismo que, segundo Castro se apóiam

\footnotetext{
[...] na implicação mútua entre unicidade da natureza e multiplicidade das culturas - a primeira garantida pela universalidade objetiva dos corpos e da substância, a segunda gerada pela particularidade subjetiva dos espíritos e do significado — a concepção ameríndia suporia, ao contrário, uma unidade do espírito e uma diversidade dos corpos. A cultura ou o sujeito seriam aqui a forma do universal, a natureza ou o objeto a forma do particular (CASTRO, p. 226)
}

Para tanto, utilizamos autores como Hudson Moura quando fala de Cinema Emergente; A Queda do Céu, livro de Davi Kopenawa e Albert Bruce; e multinaturalismo com Viveiros de Castro. Para refletir sobre o cinema indígena, os artigos de Paulo Sergio Delgado e Naine Terena de Jesus; e Gilson Moares da Costa e Galindo Dolores, do livro Povos Indígenas no Brasil: Perspectivas no fortalecimento de lutas e combate ao preconceito por meio do audiovisual. Também com os autores André Brasil, Amália Córdova, Karliane Macedo Nunes, Renato Izidoro Silva e José de Oliveira Silva. Contextualizando o cenário de festivais de cinema no Brasil, utilizaremos artigos de Tetê Mattos.

O levantamento desses festivais se deu a partir da internet, mais precisamente o facebook, meio maioritariamente usado para a divulgação desses eventos, a nível nacional e internacional. Os Festivais foram analisados a partir de esferas onde pudemos encontrar denominadores comuns no que concerne à metodologia e não só compreender sua atuação 
comum e coletiva como também singular. Aspectos como: formação, origem; número de edições; presença feminina; se há premiações ou atividades além das exibições; curadoria; perspectiva latino-americana; financiamento. Essas questões além de terem sido investigadas através de matérias na internet e monitoramento das redes sociais, também foi feita através de entrevistas com representantes dos Festivais reunidos.

Este artigo surge de um trabalho maior, apresentado como Trabalho de Conclusão de Curso, e, entendendo a dificuldade em se resumir e manter a qualidade de um estudo, optamos por não adentrar tão profundamente ao conceito de globalização e sua íntima ligação com o mundo audiovisual. Para tanto, focaremos nas questões ameríndias e dos Festivais em si.

\section{Peles de imagem}

O que conhecemos como América Latina, um subcontinente que possui tanto aspectos transversais como também distintos entre si, passou por um intenso processo colonial durante o século XV cujos desdobramentos vivemos até os dias de hoje. Começando pelo próprio nome, que indica uma origem linguística em comum: o latim, distribuído principalmente entre espanhol e português. Contudo, de acordo com o Atlas Sociolingüístico de Pueblos Indígenas en América Latina da UNICEF de 2009 (p. 14), existem contabilizadas 420 línguas indígenas existentes, provindas de 99 famílias linguísticas distintas. Como debater sobre um território tão diverso e que carrega consigo a invisibilidade dos povos que já o habitavam?

[...] ao utilizarmos termos como 'América' e 'índios' para denominarmos o continente e seus povos autóctones devemos estar conscientes do significado histórico que esses termos carregam em si mesmos para que possamos (re)construir uma história dos povos ameríndios mais livre possível dos preconceitos e estereótipos herdados dos europeus. (PEREIRA, p. 66)

Os Kunas, povos indígenas na fronteira entre Panamá e Colômbia, se referem a América Latina como Abya Yala. O nome significa Terra Viva e é utilizado desde o século XVI pelos crioulos como afirmação no processo de independência. Já a palavra 'indígena' provém do indu "de dentro" + gena "gerar" e sua etimologia, segundo el Diccionario de la Lengua Española, é definido como “'Originario del país de que se trata'. Indígena es, entonces, aquella población que habita determinado territorio desde tiempo inmemorial, desde sus lejanos antepasados" (OCHANTE, p. 1). Pensar um território que abrange múltiplas formas de viver não se trata apenas de pôr em ordens quantitativas e qualitativas os habitantes deste 
lugar, mas sim de ampliar os modos de ver, sentir e pensar; expandir e respeitar as potências com as quais co-existimos, as que aqui já estavam.

Viveiros de Castro nos convida ao multinaturalismo, um oposto ameríndio para o multiculturalismo a que se refere Lipovetsky e Serroy. Nele, a humanidade é posta como uma condição que ultrapassa a distinção clássica entre Natureza e Cultura "universal e particular, objetivo e subjetivo, físico e moral, fato e valor, dado e construído, necessidade e espontaneidade, imanência e transcendência, corpo e espírito, animalidade e humanidade, e outros tantos" (CASTRO, p. 226), pois entende os sereres vivos, quais sejam, como dignos de possuir vida e espírito.

\begin{abstract}
A tradução da 'cultura' para os mundos das subjetividades extra-humanas tem como corolário a redefinição de vários eventos e objetos 'naturais' como sendo índices a partir dos quais a agência social pode ser abduzida. O caso mais comum é a transformação de algo que, para os humanos, é um mero fato bruto, em um artefato ou comportamento altamente civilizados, do ponto de vista de outra espécie: o que chamamos 'sangue' é a 'cerveja' do jaguar, o que temos por um barreiro lamacento antas têm por uma grande casa cerimonial, e assim por diante. Os artefatos possuem esta ontologia interessantemente ambígua: são objetos, mas apontam necessariamente para um sujeito, pois são como ações congeladas, encarnações materiais de uma intencionalidade não-material. E assim, o que uns chamam de 'natureza' pode bem ser a 'cultura' dos outros. (CASTRO, p. 223).
\end{abstract}

O multiculturalismo, cuja essência consiste na interação entre culturas e povos, não abrange a violência e silenciamento envolvidos no processo colonial que forçou encontros e combinações entre comunidades diversas, muitas vezes o tratando como natural ou pacífico. A própria historiografia, por sua vez eurocêntrica, nos apresenta uma narrativa na qual a América se origina enquanto território existente a partir da chegada dos europeus, ignorando toda a população que já habitava a Abya Yala.

Sabe-se que a Europa não usou somente de armas para apagar as culturas existentes em Abya Yala, as canetas foram ferramentas dominantes e até os dias de hoje servem de fundamento para catequização, exclusão e categorização de povos, principalmente indígenas e africanos. Como se a escrita fosse hierarquicamente parte essencial do saber e qualquer que não a domine é tido como ignorante. Pereira $(2018$, p. 56) reforça que

[...] a escrita é geralmente considerada indispensável para atingir a civilização, porém os incas, que criaram um dos impérios mais notáveis da antiguidade, a desconheciam. A roda, outra invenção sempre citada como essencial nunca foi um elemento significativo na cultura aborígene no Novo Mundo. Os maias possuíam o calendário mais exato do mundo em 1492: desconheciam, porém, a tração animal e 
o ferro. A comparação cuidadosa do desenvolvimento cultural nos dois hemisférios é, portanto, a única maneira pela qual os fatores decisivos podem ser isolados e julgadas as hipóteses sobre o significado relativo das diferentes situações ambientais, sociais e históricas". (PEREIRA, 2018, p. 56)

No livro A queda do Céu, o antropólogo Bruce Albert compila passagens de entrevistas gravadas em áudios entre 1989 e 2000, feitas com Davi Kopenawa, no qual constrói uma narrativa que oscila entre "relato de vida, autoetnografia e manifesto cosmopolítico" (ALBERT, 2015, p. 43). Davi é um xamã do povo indígena Yanomami, que vive majoritariamente na fronteira entre o Brasil e a Venezuela, e inicia suas palavras apresentando-se enquanto autor da obra, cuja intencionalidade é passar aos napë $\ddot{e}^{3}$ parte do conhecimento e trajetória dos Yanomami para que sejam difundidas e estimularem o respeito a seu povo. "Eu, um Yanomami, dou a vocês, os brancos, esta pele de imagem que é minha" (2015, p. 66). Nota-se que Kopenawa emprega a expressão “pele de imagem” para referir-se aos livros, utilizado pelos brancos que, de alguma maneira, fixam a memória através de escritas em papéis.

\begin{abstract}
Os brancos se dizem inteligentes. Não o somos menos. Nossos pensamentos se expandem em todas as direções e nossas palavras são antigas e muitas. Elas vêm de nossos antepassados. Porém, não precisamos, como os brancos, de peles de imagens para impedi-las de fugir da nossa mente. Não temos de desenhá-las, como eles fazem com as suas. Nem por isso irão desaparecer, pois ficam gravadas dentro de nós. Por isso a memória é longa e forte. (KOPENAWA, 2015, p. 175)
\end{abstract}

Eu não aprendi a pensar as coisas da floresta fixando os olhos em peles de papel. Vias de verdade, bebendo o sopro de vida de meus antigos com o pó de yãkoana que me deram. Foi desse modo que me transmitiram também o sopro dos espíritos que agora multiplicaram minhas palavras e estendem meu pensamento eu todas as direções. (KOPENAWA, 2015, p. 76)

A palavra imagem está presente em toda a obra de Kopenawa, sobretudo quando nos conta sobre os rituais de yãkoana, momento em que os xamãs têm contato com os espíritos. A bebida é um alimento levado de modo intermediário pela pessoa para os xapiri que, através desse ritual, curam as doenças presentes nas pessoas da comunidade. "Quando finalmente acham a imagem cativa, eles a libertam e fogem com ela. Quando voltam para casa, recolocam a imagem dentro do corpo do doente, que acaba se recuperando" (KOPENAWA, 2015, p. 178). Alguns animais também agem como curas “Os espíritos cutia, cutiara e paco

\footnotetext{
3 "O termo Yanomami napë, originalmente utilizado para definir a condição relacional e mutável de 'inimigo', passou a ter como referente prototípico os 'Brancos', isto é, os membros (de qualquer cor) daquelas sociedades nacionais que destruíram a autonomia política e a suficiência econômica do povo nativo de referência. O Outro sem mais, o inimigo por excelência e por essência, é o Branco" (CASTRO, 2015, pp. 12-13).
} 
arrancam o mal fincado nas imagens dos humanos por seres maléficos" (KOPENAWA, 2015, p. 177).

Mal que é depositado por seres maléficos da floresta, como os ne wãri que agem não dilacerando os corpos, mas as imagens das pessoas. "Quando um desses seres maléficos resolve nos atacar, começamos de repente a gemer de dor em nossas redes. Porém, não é o corpo que ele dilacera com suas garras, e sim a imagem, que mantém presa, escondida em seu antro distante" (2015, p. 178). Assim como é na imagem que se encontra o mal, é a partir dela que se tem a cura. E em outras etnias, encontramos diferentes percepções acerca de imagem, corroborando o multinaturalismo proposto por Castro.

Esses escritos, imagens e sons são grafados e, se feito exercício, guardados para que sejam transmitidos às próximas gerações. $\mathrm{O}$ audiovisual gera essa potência, num momento da história onde as narrativas e os ensinamentos se perdem em meio a profusão de informações. Kopenawa menciona a filha que já não acompanha mais seus ensinamentos orais, não bebe a yakoana. “[...] agora, é adulta e está casada. Talvez ainda sonhe com os espíritos, mas não fala mais nisso. Seu pensamento está ocupado com muitas outras coisas". O realizador e professor Ashaninka, Isaac Pinhanta, reforça

Eu acho que o vídeo também pode ajudar a transmitir para o jovem esse conhecimento. Daqui a cinquenta anos, você pode mostrar para um jovem e vai ser muito bom a gente ver a imagem dos nossos velhos que já morreram há muito tempo. Imagina ver a imagem de um velho contando uma história de maneira tradicional, daqui há sessenta anos. Então é bom começar a registrar já. A escrita é uma coisa boa também, você pode registrar. Mas a escrita já não traz tanto, como a imagem. A imagem traz a pessoa falando lá mesmo, é a pessoa contando, é aquele velho mesmo que você vê. Então a imagem é muito bom por causa disso (PINHANTA, 2006, p. 18)

Podemos pensar o cinema - em sua raiz etimológica que nos remete ao movimento - como outra ferramenta que se enquadra em peles de imagem, com questões muito parecidas aos que diz Kopenawa sobre a literatura. Onde consegue-se, se não transmitir, pelo menos exibir percepções, histórias, contos, a várias pessoas de várias partes do mundo.

\section{Audiovisual Indígena}

O cinema aparece como uma ferramenta que por muito esteve ao serviço de uma classe dominante e, a passos lentos, mas que avançam, também é apropriada por visões outras que 
aqui apresentamos como Cinema Emergente. Os povos indígenas caminham nesse segmento, principalmente a fim de criar uma narrativa própria e vista desde a auto concepção de mundo e vida.

De um modo geral, a representação indígena na televisão e nos cinemas, principalmente quando envolve as grandes mídias, tem sido feita de modo estereotipado, não levando em consideração as multiplicidades existentes dentro da América Indígena. De outro lado, temos o cenário de indígenas que cada vez mais possui contato com o aparato audiovisual e produzindo, de modo a destacar e reivindicar sua origem. Os indígenas latino-americanos aparecem, juntamente com grupos como os LGBT, mulheres e negros, como exemplos potentes de sujeitos que se se apoderam desse uso. Santos reforça "[...] a emergência de uma cultura popular que se serve dos meios técnicos antes exclusivos da cultura de massas, permitindo-lhe exercer sobre esta última uma verdadeira revanche ou vingança." (SANTOS, 2000, p. 11)

Essa relação só é possível com a participação dos indígenas nas produções, onde suas subjetividades estão presentes. A construção audiovisual coletiva entre indígenas e nãoindígenas, porém, tardou a acontecer. Segundo Costa e Galindo (2018, p. 28), os primeiros registros de material audiovisual produzido por indígenas foram feitos nos Estados Unidos, durante a década de 1960. Uma década depois, em 1970 aparece produções no Canadá e em 1980, na Austrália. Antes disso, a temática indígena ainda estava confinada nos filmes de caráter antropológico-etnográfico feito por principalmente europeus. Pereira nos aponta que:

Desde os primórdios do surgimento do cinema, tanto na Europa como nos Estados Unidos, é possível perceber como os grandes produtores cinematográficos utilizaram-se dos filmes para projetar uma imagem do poder imperialista que visava enaltecer, interna e externamente, a 'missão civilizatória e colonizadora' europeia e americana sobre os povos africanos, asiáticos, latino-americanos, motivada, segundo a tônica do discurso imperialista, pelo desejo de levar a civilização e o progresso para locais marcados pela inferioridade racial/cultural de seus povos, pelo subdesenvolvimento econômico, pela tirania e pela doença, todos símbolos e representações negativas que justificavam a intervenção imperialista no Terceiro Mundo. (PEREIRA, pp. 73-74)

Percebemos assim como o processo multiplicador de se fazer cinema junto aos indígenas mudou em muito a direção dessas narrativas, reformulando a ideia do indígena como um objeto de pesquisa e muitas vezes visto através de um parâmetro de evolucionismo social que o põe como retrógrado. "Logo, o que diferencia a perspectiva atual é o fato de que a produção 
audiovisual indígena mostra estes povos em seu pleno dinamismo, seja para reafirmarem suas identidades coletivas e diferenciadas, seja na luta pelo respeito àquela diversidade" (DELGADO; JESUS, 2018, p. 18)

No prefácio de A queda do céu, Viveiros de Castro nos fala do "Pacto etnográfico", termo cunhado pelo co-autor do livro, Bruce Albert, expressando que não-indígena pode mostrar o indígena desde que este seja representado de forma contundente. "Os nativos aceitam se objetivar perante o observador estrangeiro na medida que este aceite (e esteja tecnicamente preparado para representá-los adequadamente perante a sociedade que os acossa e assedia" (CASTRO, 2015, p. 32. Grifo do autor).

Essa discussão, bem como a inserção dos indígenas nas produções audiovisuais foram possíveis, além da resistência constante, por alguns fatores que José Bengoa, historiador e antropólogo chileno que pesquisa a questão dos mapuches, chama de Emergência Indígena. Fatores esses que ele divide em quatro momentos: i) intensificação das políticas indigenistas nos anos 1980, cujo caráter se aproxima mais ao cultural e educacional que de violência física em si, e que proporcionou o contato indígena com ferramentas como a escrita; ii) a “Celebración de los 500 años del Descubrimiento de América”, que, em 1992, se comemorou na España e teve como reação os "500 años de Resistencia Indígena". Tal movimento, protagonizado pelos indígenas de Abya Yala, principalmente do Equador, gerou contatos entre comunidades distintas, e inclusive de países distintos, que outrora não possuíam dialogo ou sequer sabiam da existência um do outro; iii) os levantes dos indígenas do Equador e Chiapas, com o Ejército Zapatista de Liberación Nacional, ambos de forte aparição midiática; e iv) uma etapa recente, de negociações e institucionalização que perdura. (BENGOA, 2007, pp. 86-87).

A partir dos anos de 1990 com as novas tecnologias de informação e comunicação, intensificou-se o processo de homogeneização cultural, difundido a partir dos países economicamente dominantes, notadamente os de língua inglesa. A partir desse período e talvez como uma reação ao status quo, houve também o despertar de um movimento de resistência juntamente para valorizar as culturas locais, ameaçadas de desaparecimento pelo rolo compressor da globalização. Um exemplo cabal desta nova ordem local pode ser visto no dinamismo dos povos indígenas ao tornarem o áudio visual como instrumento de luta política. Os povos indígenas tomam o áudio 
visual também para reafirmarem seu modo de ser, ou igualmente o seu Indian way of life. (DELGADO; JESUS, 2018, pp. 6-7)

Temos como exemplo recente de forte aparição midiática e consumo global $\mathrm{O}$ abraço da serpente (2015), filme colombiano que passou por Oscar, Cannes, Sundance, mas também sofreu duras críticas por alguns indígenas e estudiosos, pois se trata, mais uma vez, de uma narrativa provinda da visão de um homem branco. O filme aborda o contato de um xamã, último sobrevivente de seu povo, na Selva Amazônica colombiana, com um pesquisador norte-americano. No Brasil, o filme Martírio (2017) dirigido por Vincent Carelli, fundador do projeto Vídeo nas Aldeias, aborda em duas horas e quarenta minutos o conflito entre indígenas Guarani-Kariowá e o agronegócio, reunindo materiais feitos desde 1980, com entrevistas, imagens de apoio e imagens de arquivo, fotos e até gravações dentro do Congresso Nacional. Ambos filmes, de países, etnias, e temáticas distintas, mas que rodaram festivais de tamanhos diversos, em países de todos os continentes, divulgando - às suas maneiras - questões significativas para as comunidades indígenas.

No Brasil, os primeiros registros audiovisuais de indígenas situam-se nos anos de 1914 e 1915 e foram feitos por um fotógrafo da Comissão Rondon, que captou alguns aspectos cotidianos do Povo Bororo, no Mato Grosso (COSTA; GALINDO, 2018, p. 25). Ou seja, a temática indígena está presente no cinema nacional desde sua origem e "[...] vem contribuindo para a construção de uma imagem dos grupos e sujeitos indígenas que nos situa em termos de bons e maus selvagens face aos preceitos conceituais como civilização, nacional e Estado. (NUNES; SILVA; SILVA, 2014, p. 4). Porém, apenas em 1970 tem-se registro de um filme de temática indígena feita com participação dos próprios indígenas, que é o Conversas de Maranhão, de Andrea Tonnaci. Momento esse em que o movimento indígena se consolida enquanto movimento organizado. (DELGADO, 2018, p. 215). Esse cenário foi essencial para a criação do projeto que intensificou a produção audiovisual indígena no Brasil: o Vídeo nas Aldeias.

O VnA existe desde 1986, fundado pelo antropólogo francês Vincent Carelli, juntamente com sua ex-companheira já falecida e também antropóloga, Virgínia Valadão. Desde então o projeto vem documentando povos e formando cineastas indígenas e, exatamente por isso, possui grande reconhecimento dentro e fora do território nacional, sendo de extrema importância para o cenário do cinema indígena brasileiro. Em 1999, recebeu o Prêmio Unesco 
pelo respeito à diversidade cultural e pela busca de relações de paz interétnicas; em 2009, Ordem do Mérito Cultural pelo então presidente Lula.

Recentemente, em abril deste ano, no marco do dia do índio, foi lançado um streaming com um total de 88 filmes, feitos por indígenas ou não-indígenas que dialogam sobre as questões que envolvem diversos povos do Brasil. O stream funciona on demand da plataforma Vimeo e “Os valores de aluguel ou compra dos filmes vão de US\$ 1 a US\$ 4. A verba arrecadada será distribuída entre o cineasta indígena (35\%), a comunidade registrada (35\%) e o projeto Vídeo nas Aldeias (30\%), para ações e manutenção do acervo". A filmoteca funciona também como uma espécie de acervo online dos filmes que remontam às origens e às produções mais atuais, como o próprio Martírio.

Como consequência dessas formações, hoje há certa autonomia dos indígenas já formados, que acabam também formando as próximas gerações, fazendo com que o Brasil hoje possua muitos nomes quando se fala em cineastas indígenas. Como Alberto Alvares, Divino Tserewahú, Takumã Kuikuro, Kamikia Kisêdjê, Yaiku Suya, Zezinho Yube, etc. Assim como tem crescido o número de mulheres indígenas fazendo cinema, como Larissa Ye'padiho, Graci Guarani, Pateani Huni Kuin, Patrícia Ferreira Keretxu, Suely Maxacali e Olinda Muniz. Também há produtoras voltadas diretamente para a produção audiovisual de temática indígena como a Pajé Filmes e inúmeras iniciativas audiovisuais dentro de comunidades indígenas. "A divulgação dessas produções se expandiu para contexto internacional a partir de eventos e licenciamento de conteúdos para canais de televisão fechada e recentemente pelo Netflix, como foi o caso do Hipermulheres de Takumã Kuikuro.” (DELGADO; JESUS, 2018, pp. 12-13. Grifo dos autores)

Tendo em vista que o acesso ao cinema ainda é limitado, e que existe uma parcela considerável $^{4}$ de indígenas no Brasil que resistem ao contato físico com o exterior de sua comunidade, não pode ser considerada um aparato que alcança a todos. Além de seu próprio custo de produção. Os indígenas que produzem ainda dependem bastante de políticas públicas, através de pessoa física, coletivos, ONGs etc.

\footnotetext{
${ }^{4}$ De acordo com Munuruku (2018, p. 172), atualmente no Brasil existem contabilizados 55 grupos indígenas nesta situação.
} 
Este ano o Ministério da Cultura divulgou os Editais \#AudiovisualGeraFuturo, em que um deles é para produção independente de documentários a partir de 52 minutos com temáticas voltadas à cultura afro-brasileira e indígena. Outra delas, para Festivais, Mostras, Premiações, Eventos de Mercado e Ações de Promoção/Difusão da Produção Audiovisual Nacional, mas apenas para festivais e mostras com no mínimo cinco edições já realizadas. Em todos eles há cotas específicas (com percentuais distintos) para os segmentos: novos diretores, diretores de regiões fora do eixo Rio e São Paulo, negros, indígenas e mulheres.

O próprio Vídeo nas Aldeias tem perdido bastante recursos, desde 2010 não recebe recursos do Ministério da Cultura e este ano perdeu seu maior apoio, que vinha da Noruega e desde então fechou sua sede. Carelli, em entrevista ao Jornal Nexo, expôs que "Temos algum apoio para fazer filmes, vindo do Funcultura [edital para o audiovisual do estado de Pernambuco], mas não pra fazer formação que é o nosso diferencial", e que "É um momento de contradição. Esse é o ano que Martírio está bombando, o Vídeo nas Aldeias está na Bienal [de Arte de SP]. Nunca tivemos tanta visibilidade e tanto reconhecimento em todos esses anos, e nunca tivemos tanta dificuldade financeira"

La circulación de estos trabajos continúa siendo bastante limitada. Se realizan muestras comunitarias con cierta frecuencia, pero son esporádicas y no cuentan con financiamiento estable. Los líderes políticos hacen uso del video para fines educativos y para sus giras por diversas regiones y países. Son los festivales internacionales los que les dan mayor visibilidad a los trabajos. (CÓRDOVA, 2011, p. 98)

Córdova reforça, então a importância dos Festivais como meio de divulgação das obras produzidas.

\section{Festivais de cinema}

Os Festivais de Cinema foram e são espaços de encontros e de formação de público, entre os mais diversos tipos de pessoas que, de alguma maneira, se interessa ou relaciona - e às vezes nunca teve contato - com a arte cinematográfica para se consumir e debater não só o produto fílmico em si, mas pensando todas as fases de produção. Um espaço que dialoga com basicamente todas as etapas do cinema e evidencia a troca entre culturas e localidades diversas.

Se retomarmos a origem da palavra 'festival', esta se assemelha a palavra 'festa', cujo significado remete à ideia de celebração, de congraçamento, de entrelaçamento de pessoal. A palavra também pode remeter à inovação, novidade, invenção, transformação. Os festivais também exercem um poderoso papel de protagonismo nos processos de transformação simbólica das sociedades na medida em que são 
pela sua própria natureza, muito ritualizados, midiatizados e espetacularizados. Estas características podem ser preciosas chaves de inteligibilidade da potencialidade do segmento festivais de cinema na pós-modernidade. (MATTOS, p. 4)

A origem dos Festivais, entretanto, remete a governos autoritários ou de tendências nacionalista, como nos aponta Itier. O primeiro que surgiu foi em Venecia, en 1932, sob governo de Mussolini; e Cannes, em 1939 (sua primeira versão se realizou em 1946, após a Segunda Guerra Mundial). Na América Latina o primeiro festival que se tem registro é o Mar del Plata, que foi fundado em 1954 durante o governo de Perón. Mostrando assim como os Festivais são momentos e espaços cruciais para demonstração, circulação e alcance de poder político, cultural ou econômico. No Brasil, o primeiro a surgir foi o Festival de Brasília em 1965 (inclusive, por seu caráter questionador foi censurado durante o regime militar, entre os anos de 1972 e 1974).

De maneira que, ressignificados, tornam-se espaços potentes e fundamentais para a vitalidade do Cinema Emergente, pensando principalmente o contexto latino-americano, em que não há tantas salas de cinema, e a maioria delas se encontra restrita às grandes cidades e, pelos custos que carrega, é muitas vezes inacessível às parcelas de pouco poder aquisitivo. Os Festivais nesse sentido atuam de pelo menos duas maneiras distintas da lógica das salas de cinema comerciais - hoje massivamente encarceradas nos shoppings centers - tornando a grande tela mais acessível; primeiro, realizando sessões e eventos não pagos e segundo, fazendo essas mesmas atividades em espaços que não o do cinema dito (a sala fechada, escura, climatizada), mas ocupando lugares públicos e abertos, como praças, ruas, aldeias, parques, etc.

O Fórum dos Festivais (Fórum Nacional dos Organizadores de Eventos Audiovisuais Brasileiros) destaca em seu site que "os festivais audiovisuais brasileiros possuem forte atuação cultural, social e econômica, estimulando a formação de plateias, garantindo espaço para nossos filmes, promovendo o acesso da população às telas e gerando emprego e renda em todas as comunidades onde atua". O Fórum é um dos setores que promovem e investigam o ramo de Festivais no Brasil, ele foi criado em 2005 e estabeleceu o Código de Ética do Fórum dos Festivais e também promoveu o Diagnóstico dos Festivais Audiovisuais (de 2006 a 2009, divididos em dois estudos), coordenado por Tetê Mattos e Antonio Leal, ambos ligados ao Fórum. Em 1999, foi criado Guia Brasileiro Festivais de Cinema e Vídeo; em 2011 o Guiafala - Guia de Festivais Audiovisuais Latino-Americanos. Ainda, IBEFEST - Instituto Brasileiro de Estudos de Festivais Audiovisuais, a Associação Cultural Kinoforum e o mapeamento de Festivais da Ancine, a nível nacional. 
O Painel Setorial dos Festivais Audiovisuais, que tem como marcos de estudo os anos 2007, 2008 e 2009, traz números interessantes para se pensar a atuação desses eventos nas comunidades e no Brasil de forma geral, pensando em todos as etapas envolvidas para sua realização. Em 1999, o número de Festivais de Cinema existentes em território brasileiro era de 38, em 2009 alcançou o marco de 243 (p. 22). Dentro dessa pesquisa, podemos observar, a partir da categorização dos festivais a partir de temáticas, que em 2006 não existia Festivais de Cinema Indígena, enquanto em 2009 constatou-se apenas um (e três etnográficos).

São diversos os setores movimentados no que tange à realização dos Festivais. Mattos e Leal (p. 53) enumeram alguns como: produção, curadoria, tradução, consultoria, publicidade, designer, hotelaria, transporte aéreo e local, artesanato, fotografia e vídeo, segurança, alimentação, turismo, etc. Mattos, em seu texto "Festivais pra quê? Um estudo crítico sobre festivais audiovisuais brasileiros" também agrupa campos de conhecimento e prática que são fomentados nos Festivais, sendo eles exibição e difusão (vitrines), formação (oficinais), reflexão (debates) e produção (concursos).

O leque de setores e atividades envolvidas acentua a importância desses eventos para geração de renda, movimentação de capital, estimulação a produção cultural e encontros internacionais e multidisciplinares e multiculturais, características inerentes ao contexto de globalização. "Diante de um cinema que se anuncia 'global', e ao mesmo tempo fragmentado, pluri-identitário e multiculturalista, seriam os festivais de cinema como lugares de troca transculturais?" (MATTOS, p. 4). Por gerar tantos recursos, envolvendo aí também nomes importantes de realizadores, produtoras, setores governamentais e privados, e por sua intensa condição de vitrine, acaba por atrair forte presença midiática, tornando-se um espaço espetacularizado, cuja característica é inerente aos eventos culturais

\footnotetext{
"[...] que, por sua vez, possuem importante significação cultural numa sociedade em que se apresenta cada vez mais ancorada no espetacular. Todo o aparato que envolve um festival de cinema, como as celebridades (tapete vermelho, glamour), presença de cineastas, o forte interesse da mídia e dos críticos, a publicidade, direção de espetáculo cênico (mestre de cerimônias, iluminação etc.), aproximam esta manifestação cultural ao entretenimento, e dessa forma geram forte interesse no público presente. Os festivais se apresentam como uma ferramenta estimuladora, multiplicadora e arregimentadora de plateias e de formação de público para um modelo de cinema que não encontra espaços de veiculação frente aos padronizados mercados hegemônicos" (MATTOS, p. 129)
}

De maneira que muitos desses grandes eventos, como o Festival de Cannes na França, ou o Festival de Brasília no Brasil têm sido palcos de protestos e denúncias, cujo destaque midiático envolvido se torna ferramenta para que cineastas difundam suas bandeiras dentro 
não só da História, mas do espaço cinematográfico em si, para que a espetacularização não seja a essência de convergências tão potentes. Em maio deste ano o tapete vermelho de Cannes teve protestos de 82 mulheres estrelas do cinema reclamando igualdade de participação em funções e salários; também de cineastas brasileiros com cartazes em vários idiomas reivindicando a demarcação dos territórios indígenas.

\section{Os Festivais de Cinema Indígena no Brasil}

O primeiro registro de um Festival voltado exclusivamente à temática indígena na América Latina é de 1985, no México, com o I Festival Latinoamericano de Cine y Video de los Pueblos Indígenas. Esse evento surgiu simultâneo a origem da Coordinadora Latinoamericana de Cine y Comunicación de los Pueblos Indígenas (CLACPI), que hoje conta com vários parceiros não só em território latino-americano como também europeu e norte-americano. $\mathrm{O}$ Festival seguiu suas edições no Brasil (1987), seguido da Venezuela (1989), do Peru (1992), e da Bolívia (1996). O Festival ainda acontece, num intervalo de dois anos, e sua atual edição (13o) acontece na Guatemala entre 2017 e 2018. Córdova, sobre a significação desses espaços, aponta que:

\footnotetext{
Para ayudar a la difusión de estas importantes obras, han surgido importantes espacios en festivales internacionales de cine, y se han creado festivales especialmente abocados al cine indígena. Éstos se convierten en eventos emblemáticos que hacen visible una comunidad global de video indígena, que reúnen obras y productores geográficamente muy dispersos, generando espacios fértiles para el debate sobre los derechos indígenas y la representación, abriendo fuentes de apoyos e intercambios, facilitando la circulación de obras devuelta a las comunidades indígenas y aún más allá. Se trata de una red de solidaridad comprometida con los contenidos y los realizadores de estos videos. (CÓRDOVA, pp. 87-88)
}

Tem-se como exemplos atuais na América Latina, dentre tantos, os seguintes Festivais e Mostras: Arandu- Muestra Latam de Cine Indígena y Comunitario e Festival de Cine Buenos Aires Indígena BAIn na Argentina; Festival Internacional de Cine Indígena de Wallmapu, TUWUN - Muestra de Cine Indígena de Wallmapu, Muestra Cine + Vídeo Indígena, Muestra de Cine América Indígena, Festival Internacional de Cine y Video Mapuche y del Abya Yala, Fantepu, no Chile; DAUPARÁ - Muestra de Cine y Video Indígena en Colombia, Festival Cine y Video indígena Rodolfo Maya na Colômbia; Jumara Festival Internacional de Cine Indígena de Panamá; Muestra Internacional de Cine y Video Indígena MICVI; Festival de Cine y Video Indígena (FECVI); Festival Internacional de Cine y Video Indígena "Mirando desde Nuestra Raíz" no México; Festival internacional de cine y comunicación de los pueblos indígenas/originarios FICMAYAB na Guatemala; Festival Internacional de los Pueblos 
Indígenas (FIPI) na Venezuela; e Festival de Cine Indígena: Rayo de Luz que Vivifica la Tierra em El Salvador.

De acordo com Córdova (p. 103), “Actualmente existen más de sesenta y cinco festivales de cine especializados en el cine y video de los pueblos indígenas, de los cuales casi la mitad se realizan en Estados Unidos y seis en Canadá". Podemos concluir que são iniciativas que têm crescido, sendo de extrema importância para a distribuição - uma das fases mais penosas do cinema indígena - entretanto, é justamente esse empecilho que também esbarra na lógica muitas vezes excludente dos Festivais, pois:

Las obras son producidos de forma colaborativa, dando lugar a formas híbridas, variados géneros e innovadoras metodologías que operan dentro de los valores tradicionales de reciprocidad. Como resultado, las producciones varían mucho en duración y tiempo de producción, lo que dificulta la postulación de proyectos para concursos y la planificación de estrenos de películas para festivales. Además, las obras pueden tener diferentes versiones para su distribución a los públicos internos y externos, y rara vez se producen con material promocional, fotografías en alta resolución, trailer o página web. (CÓRDOVA, p. 92)

O levantamento dos Festivais de Cinema Indígena no Brasil, como dito anteriormente, se deu através de redes sociais e plataformas de busca online, entre maio e junho de 2018. A partir dessa busca, constatamos a presença de oito desses Festivais no Brasil atualmente, a saber: i) Bienal Cinema Indígena - Aldeia SP; ii) Mostra Paraguaçu de Cinema Indígena; iii) Cine Kurumin; iv) Cine Tekoha - Mostra de Cinema Indígena do Colégio Pedro II; v) Tela Indígena; vi) Mostra Amotara - Olhares das Mulheres Indígenas; vii) Mostra Indígena de Filmes Etnográficos do Ceará; e viii) Mostra Cine Índio Brasil. A partir desse levantamento, contactamos os Festivais para que pudessem responder à entrevista, e dos oito, apenas quatro o fizeram. Também foi elaborado um mapa, através da plataforma Snazzy Maps, repositório do Google Maps, com os Festivais em seus locais de atuação, como podemos ver a seguir: 


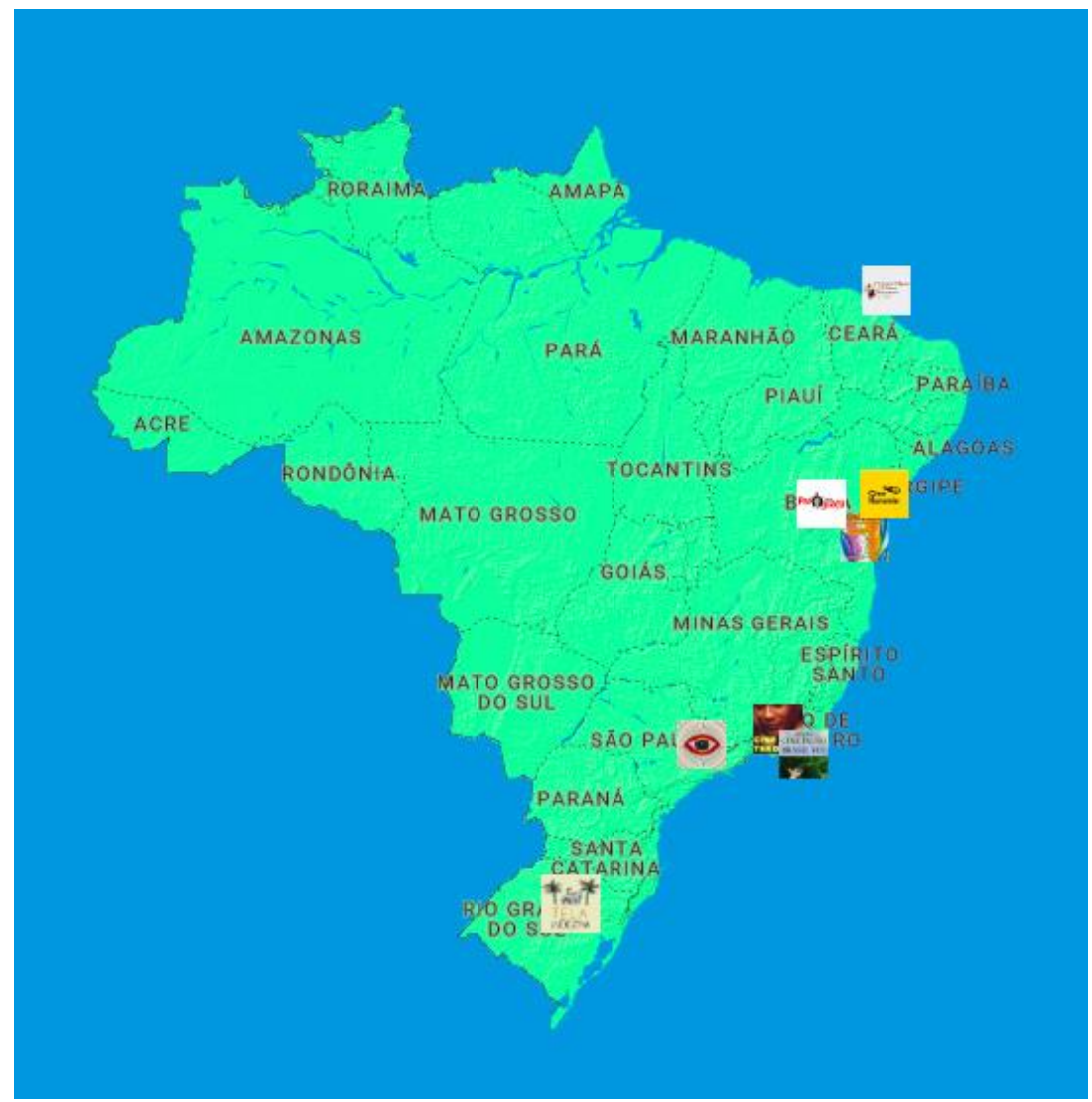

Anexo 1 - Festivais de Cinema Indígena no Brasil (2010-2018)

Fonte: criação da autora através do Snazzy Maps

A Bienal de Cinema Indígena, cujo nome na primeira edição foi Aldeia SP, acontece no Centro Cultural São Paulo e nos CEUS da capital paulista. O evento, que está em sua segunda edição, é uma realização de Ailton Krenak e curadoria de Pedro Portella. Em outubro deste ano, foram exibidos 53 filmes - sendo 11 com mulheres na produção e/ou direção - dentre “clipes de música, ficções e documentários realizados nos últimos seis anos e de diferentes extensões. Muitos têm legendas em português e reivindicam temas, histórias e personagens marginalizados ao longo do tempo".

No Município de Pau Brasil, Sul da Bahia, acontece a Mostra Paraguaçu de Cinema Indígena, no Colégio Estadual da Aldeia Indígena Caramuru Paraguaçu, na Terra Indígena Caramuru Paraguaçu. A programação é composta por cerca de 16 obras audiovisuais, feitas por indígenas e não-indígenas, sendo os participantes todos indígenas. Além da própria mostra, há exposição de artefatos dos indígenas, oficina de audiovisual para crianças e oficina para orientação dos realizadores indígenas quanto ao seu registro como Agente Econômico na ANCINE e a solicitação do Certificado de Produto Brasileiro (CPB) de suas obras 
audiovisuais.

Segundo Olinda Muniz, idealizadora, curadora, coordenadora, organizadora e diretora da mostra "A ideia surgiu da necessidade de dar visibilidade aos cineastas indígenas e construir um intercâmbio pelas aldeias. Como o Festival Paraguaçu é um Festival que está iniciando, não contamos com apoio financeiro o que acarretou um excesso de trabalho para os realizadores" e que "o cinema tem dado a oportunidades para essas comunidades se expressarem e de certa forma ajuda a acabar com o preconceito e estereótipo que a sociedade ocidental tem dessas populações”.

O Cine Kurumin é uma das maiores referências latino-americanas quando se trata de Festivais de Cinema Indígena. O festival, que acontece no estado da Bahia, começou em 2011, atuando nas aldeias Tupinambá, Pataxó e Tumbalalá, com apoio financeiro do Instituto de Radiodifusão da Bahia (Irdeb). Logo se estendeu, chegando a capital Salvador e em Yawalapiti, no Parque Indígena do Xingu, MT, e, conforme a coordenadora e curadora do Festival, Thais Brito, o evento chega "a reunir um público de aproximadamente 800 pessoas nas aldeias e mais de 2000 pessoas em Salvador". A curadoria da última edição do Festival, em 2017, foi feita por uma equipe completamente feminina e conteve em sua programação um total de três mostras especiais, sendo uma delas a Mostra Cinema das Mulheres Indígenas que "apresenta um breve recorte da produção audiovisual contemporânea realizada por mulheres indígenas no continente americano".

De todos os Festivais, o único que possui premiação é o Cine Kurumin, com quatro categorias: Melhor média/longa-metragem, Menção honrosa média/longa-metragem, Melhor curta-metragem e Menção honrosa curta-metragem. Sobre a relação da importância desses festivais específicos para o cinema indígena, Thais afirma que "A produção dos realizadores indígenas impulsionou também que existissem mais festivais e não só isso, mas que os festivais que os filmes indígenas ocupassem espaço dentro de festivais com temáticas mais gerais. Então acho que foi também a produção indígena que impulsionou o crescimento dos festivais e a importância do cinema indígena em festivais no geral. O que acho importante dos festivais, principalmente os que são específicos para o cinema indígena e premia o cinema indígena como o Cine Kurumin, a gente consegue, de alguma forma, dar visibilidade a filmes que talvez não entrassem em circuitos normais de festival. As questões, as estéticas, as linguagens, as formas que não necessariamente costumam circular em outros meios. Não por 
conta dos nossos festivais, mas por conta também da ação dos povos indígenas que faz do audiovisual do cinema indígena, que faz a gente alargar um pouco essa noção do que é cinema, compreender os contextos de produção da aldeia, a importância de cada temática. Acho que é uma relação de viés duplo, tanto a produção e impulsão dos festivais, como também os festivais impulsionam a produção do cinema indígena".

O Cine Tekoha possui uma singularidade dentre os Festivais aqui mapeados, pois é o único totalmente voltado ao meio escolar, neste caso, atuando no Colégio Pedro II, instituição de ensino público federal e o terceiro mais antigo do Brasil. A mostra é uma realização da organizadora Sabrina Alvernaz, e, de acordo com ela, foi uma atividade inspirada no Cine Kurumin e impulsionada pela Lei 11.645/2008, que torna obrigatória a presença da temática "História e Cultura Afro-Brasileira e Indígena" no currículo oficial da rede de ensino. Sobre a curadoria explica que "Dos seis curtas exibidos, quatro deles eram de autoria indígena. Em nossa seleção, priorizamos criar espaço para a voz e a imagem 'pelos' povos originários, mais do que 'dos' povos originários. Concomitantemente, é necessário pontuar que o que nos movia era a arte cinematográfica em si ou o que o filme era capaz de fazer no espectador".

Em Porto Alegre, desde 2016, acontece o Tela Indígena, que este ano teve sua terceira edição. Nele, foram exibidos 27 filmes realizados por indígenas ou de temática indígena, provindo de quatro países diferentes - Brasil, Argentina, México e Canadá. Essa edição, diferente das outras, sofreu modificações por contar com investimento do Ministério da Cultura. Enquanto nos dois primeiros as mostras ocorreram uma vez por mês, este ano aconteceu durante uma semana de setembro. Segundo Marcus A. S. Wittmann, curador e programador do Festival: "A ideia surgiu de algumas reunioẽs do Núcleo de Antropologia das Sociedades Indígenas e Tradicionais (NIT/UFRGS), do qual fazem parte diversos alunos de graduação em Ciências Sociais e Mestrado e Doutorado em Antropologia Social. Já havíamos realizado alguns eventos com exibição de filmes, mas ficávamos um pouco frustrados pelos eventos sempre reunirem pouco público e ficarem restritos ao ambiente acadêmico. Então começou a surgir a ideia de ampliar esse tipo de evento com discussões sobre a temática indígena. No mesmo período, houve um caso de um estudante indígena ser espancado em frente à moradia estudantil da Universidade. Sendo o Rio Grande do Sul um estado muito arraigado no racismo, em uma ideologia anti-indígena e no agronegócio começamos a pensar em meios de conversar com um público mais amplo sobre essas diferentes questões e aproximar os 
indígenas do Estado, em um primeiro momento aqueles da região metropolitana de Porto Alegre, de uma parcela da sociedade que tem pouco contato com eles".

O Festival exibe longas e curtas-metragens feitos por indígenas ou não-indígenas, e além disso amplia a os meios de difundir a cultura ameríndia através de rodas de conversa com os realizadores e lideranças indígenas, exposição de artesanatos e obras pictóricas, instalação audiovisual etc. Para Marcus, essas atividades são essenciais para que "público pudesse conhecer as diferentes realidades dos povos e potencializar as discussões", e reforça a potência do cinema nesse sentido: "Quando pensamos em cinema indígena não estamos apenas demarcando telas de cinema, mas demarcando também a mente e o público das pessoas, através de um discurso que se apropria de uma cultura visual de comunicação. Essas produções audiovisuais e esses Festivais e Mostras (que muitas vezes são os únicos lugares de exibição para um publico maior desses filmes) funcionam com um modo de aproximação entre os indígenas, suas demandas, suas culturas e suas sabedorias de um publico que muitas vezes não tem possibilidade de se locomover até uma aldeia, ou não conhece esses povos e não tem a sensibilidade para compreender suas lutas. Tanto o cinema indígena, quanto os festivais e mostras com essa temática são e devem ser populares".

Outro caso de festival com vertente específica, mas voltada a temática dentro das questões ameríndias, é Mostra Amotara - Olhares das Mulheres Indígenas, que traz um panorama do cinema feito por mulheres indígenas brasileiras. O festival é uma iniciativa da professora Joana Brandão (UFSB) em parceria com o Imagina! Circuito Permanente de Audiovisual e acontece em território baiano, abarcando três localidades distintas: Caravelas, na sede do Movimento Cultural Arte Manha; Teixeira de Freitas, no campi da UFSB Paulo Freire e Porto Seguro, em Sosígenes Costa, Centro Cultural de Porto Seguro e Aldeia Indígena Jaqueira.

A Mostra Indígena de Filmes Etnográficos do Ceará, festival internacional que ocorre desde 2015 na Aldeia Lagoa Encantada em Aquiraz, é uma realização Associação das Mulheres Indígenas Jenipapo-Kanindé e conta com os indígenas Jenipapo-Kanindé no proceso de produção e curadoria. O Festival também contou, na sua última edição em 2017, com uma mostra voltada às mulheres, chamada Espiritualidade Feminina.

Por fim, temos a Mostra Cine Índio Brasil, a mais antiga e, portanto, com mais edições. A Mostra surgiu em 2010 é voltada ao público escolar do Rio de Janeiro, também uma iniciativa fomentada pela Lei 11.645/2008, mas que, diferente do Cine Tekoha, é aberto ao público em 
geral. A mostra conta com exibição de um longa-metragem destaque e curtas-metragens, seguido de debate com realizadores. Em todas as edições há um(a) realizador(a) homenageado e também apresentações artísticas, exposição de artesanato e alimentação típica.

Os patrocínios, no geral, vêm de editais. O Tela Indígena teve financiamento do Ministério da Cultura através de um Edital de apoio a Mostras e Festivais audiovisuais em sua terceira edição, o que fortaleceu e ampliou. A Mostra de Filmes Etnograficos do Ceará também recebeu patrocínio através do Edital Secretaria da Cultura do Estado do Ceará (Secult). Sabrina Alvernaz explica que com o Tekoha "As exibições geraram muitos afetos e reflexões, tanto foi assim que o que começou sem financiamento algum acabou mobilizando duas fontes de custeio, sendo o SINDSCOPE (Sindicato dos Servidores do Colégio Pedro II) e a ADCPII (Associação de Docentes do Colégio Pedro II). O valor arrecadado permitiu o deslocamento e o pró-labore do diretor guarani”. A Mostra Cine Índio Brasil conta com patrocínio da Distribuidora de Filmes S.A - RioFilme.

Também pudemos constatar a presença de Mostras que são mais esporádicas ou fazem parte de uma programação maior, como: I Encontro da Cultura Cinematográfica do Xingu 2018 (Xingu/MT); Mostra Permanente de Cinema de Povos Indígenas e Tradicionais (Forianópolis/SC); Anauê - Mostra de Cinema Indígena (Garanhuns/PE); Mostra de Cinema Xavante (Belo Horizonte e Uberlândia/MG; Barra das Garças/MT); Mostra Nosso Olhar (Niterói/RJ); Mostra Territórios Audiovisuais Indígenas, dentro do 51o Festival de Brasília; e o Mekukradjá - Círculo de Saberes: o Movimento da Memória, uma Mostra de filmes on-line compondo a programação do Itaú Cultural.

\section{Considerações finais}

É preciso ressignificar o modo como vemos o mundo, a vida, o cosmos. Através, e não por cima de outras vidas, da mesma maneira a urgência de descolonizar o fazer e o ver cinema. Num cenário onde as imagens e os meios de transmiti-las estão cada vez mais presentes na rotina das pessoas, torna-se uma ferramenta não obrigatória, mas multiplicadora. Os Festivais nesse sentido são espaços de encontro e interação que encontra o audiovisual como meio de fazê-lo, tornando o filme não um fim em si mesmo a partir de sua exibição, mas um propagador de imagens vozes que precisamos ver e escutar.

Durante a pesquisa, encontramos grande força no cinema feminino, especialmente em mostras 
exclusivas e presença na coordenação e curadoria, tornando um espaço de difusão não só de obras audiovisuais feitas por mulheres, mas também como espaços de discussão e fortalecimento. Com o levantamento, podemos perceber também o quanto o cinema indígena e os Festivais ainda dependem de políticas públicas no que tange a criação e permanência. E ao pensar no cenário em que se encontra (e o que aguarda) para o Brasil e América Latina, sabendo que esses recursos diminuirão e a sobrevivência se tornará mais perigosa ainda, faz com que esses eventos sejam ao mesmo tempo ameaçados e mais potentes. E por mais que permaneça restrito a muitos, carrega em si a essência coletiva e celebra a criação: que foi, que está, que virá - uma festa!

Que as visões sejam compartilhadas em aldeias, praças, teatros, cinemas, corredores, palcos, escolas, centros culturais, onde se façam perpetuar e ecoar as palavras dos habitantes originários de Abya Yala.

\section{Referências bibliográficas}

BENGOA, José. La emergencia indígena en América Latina. Santiago de Chile e México: Fondo de Cultura Económica, 2007.

BRASIL, André. Ver por meio do invisível: o cinema como tradução xamânica. Disponível em:

http://www.academia.edu/30373651/Ver_por_meio_do_invis\%C3\%ADvel_o_cinema_como tradução_xamânica Acesso em: 23 de outubro de 2018.

CANCLINI, Néstor García. A globalização imaginada. São Paulo: Editora Iluminuras, 2007.

CASTRO, Eduardo Viveiros de. Perspectivismo e multinaturalismo na América indígena. Disponível em: http://oquenosfazpensar.fil.pucrio.br/import/pdf_articles/OQNFP_18 13 eduardo_viveiros de castro.pdf Acesso em: 09 de maio de 2018.

. O recado da mata. Prefácio. In: A queda do céu. ALBERT, Bruce; KOPENAWA, Davi. São Paulo: Companhia das Letras, 2015.

CÓRDOVA, Amália. Estéticas enraizadas: aproximaciones al video indígena en América Latina. In: Comunicación y Medios n. 24. Universidad de Chile, 2011.

COSTA, Gilson Moares da. GALINDO, Dolores. Produção audiovisual no contexto dos povos indigenas: transbordamentos estéticos e políticos. In: Povos Indígenas no Brasil: Perspectivas no fortalecimento de lutas e combate ao preconceito por meio do audiovisual. Curitiba: Editora Brazil Publishing, 2018. 
DELGADO, Paulo Sergio; JESUS, Naine Terena de. Prefácio; Apresentação. In: Povos Indígenas no Brasil: Perspectivas no fortalecimento de lutas e combate ao preconceito por meio do audiovisual. Curitiba: Editora Brazil Publishing, 2018.

ITIER, Sebastián González. Estudiando el circuito de festivales de cine en Chile: Una deuda en la investigación sobre cine chileno. Disponível em: http://www.lafuga.cl/estudiando-elcircuito-de-festivales-de-cine-en-chile/861 Acesso em: 17 de novembro de 2018, às 23:21.

KOPENAWA, Davi. AlBERT, Bruce. A queda do céu. São Paulo: Companhia das Letras, 2015.

LIPOVETSKI, Gilles; SERROY, Jean. A tela global: mídias culturais e cinema na era hipermoderna. Porto Alegre: Sulina, 2009.

MATTOS, Tetê. LEAL, Antonio. Festivais Audiovisuais Brasileiros: um diagnóstico do setor. Disponível em: http:/www.cult.ufba.br/enecult2009/19077.pdf Acesso em: 28 de março de 2018.

MATTOS, Tetê. Festivais de cinema e a nova lógica do consumo cultural - o caso do Cinefoot. Disponível em: $\quad$ http://www.labaudiovisual.com.br/labav/wpcontent/uploads/2017/10/FESTIVAIS-DE-CINEMA-E-A-NOVA-L\%C3\%93GICA-DOCONSUMO-CULTURAL-\%E2\%80\%93-O-CASO-DO-CINEFOOT.pdf Acesso em: 28 de março de 2018.

. Festivais pra quê? Um estudo crítico sobre festivais audiovisuais brasileiros. In: BAMBA, Mahomed (org). A Recepção Cinematográfica. Salvador: EDUFBA, 2013.

MOURA, Hudson. O cinema intercultural na era da globalização. In: FRANÇA, Andréa França; LOPES, Denilson (orgs). Cinema, globalização e interculturalidade. Chapecó: Argos, 2010

NUNES, Karliane Macedo; SILVA, Renato Izidoro; SILVA, José de Oliveira dos Santos. Cinema indígena: de objeto a sujeito da produção cinematográfica no Brasil. In Polis, Revista Latinoamericana, Volumen 13, No 38, 2014, pp. 173-204.

OCHANTE, Alejandro Estrada. Indígena sí, índio no. Disponível em: http://www.minedu.gob.pe/udena/xtras/indigena_si_indio no.pdf Acesso em 30 de julho de 2018 , às $22 \mathrm{~h} 03$.

PEREIRA, Wagner Pinheiro. História da América Indigena: as representações das civilizações ameríndias pré-colombianas e da conquista européia do continente americano na historiografia e no cinema. In.: PAREDES, Beatriz. (Coord.). O mundo indígena na América Latina. São Paulo: Editora da Universidade de São Paulo, 2018.

PINHANTA, Issac. Você vê o mundo do outro e olha para o seu. In: Catálogo Mostra Vídeo nas Aldeias: um olhar indígena. Banco do Brasil, 2006.

SANTOS, Milton. Por uma outra globalização. Rio de Janeiro: Editora Record, 2000. 
UNICEF. Atlas Sociolingüístico de Pueblos Indígenas en América Latina. Disponível em: https://www.unicef.org/honduras/tomo 1 atlas.pdf Acesso em 30 de julho de 2018, às 20h13. 